Proc. Estonian Acad. Sci. Geol., 2003, 52, 3, 155-178

\title{
Clastic dikes in Middle Devonian sandstones of the Gauja Formation, southeastern Estonia
}

\author{
Anne Kleesment ${ }^{\mathrm{a}}$, Väino Puura ${ }^{\mathrm{b}}$, and Toivo Kallaste ${ }^{\mathrm{a}}$ \\ a Institute of Geology at Tallinn Technical University, Estonia pst. 7, 10143 Tallinn, Estonia; \\ kleesmen@gi.ee \\ ${ }^{\mathrm{b}}$ Institute of Geology, University of Tartu, Vanemuise 46, 51014 Tartu, Estonia
}

Received 6 May 2002, in revised form 18 July 2002

\begin{abstract}
Clastic dikes of sedimentary origin are exotic, but still remarkable minor geological structures in the Lower Palaeozoic sequence of northern Baltoscandia. They often carry essential information about the processes and environments that governed during sedimentary breaks. The first up to $10 \mathrm{~cm}$ wide clastic dikes in the Devonian sequence of Estonia were found in sandstones of the Gauja Formation in Piusa and Tabina glass sand quarries. Field observations, lithological, mineralogical, and geochemical studies of dikes revealed that these dikes were formed during a short sedimentary break at the end of the Middle Devonian. Eluvial sediments that were partly cemented in tropical arid conditions were the probable source of sandy matrix of dikes and abundant clasts embedded in it. Gravitational failure and temporary water stream processes were the ways of mass transport into the fractures. However, the amount of water was not large enough to fill the fractures and to cause any kind of stratification during the withinfracture sedimentation.

Local uplift of the area and extensional deformation of rocks with the formation of open fractures in Middle Devonian layers suggest a tectonic phase in the vicinity of the regional Liepaja-Riga-Pskov zone of tectonic dislocations. This regional zone was formed due to the Late Caledonian compression and was afterwards recurrently activated. Opening of the fractures was immediately followed by filling. At that moment the levels observable in the present sandstone quarries must have been located more than $20-30 \mathrm{~m}$ above the groundwater level. Subsequent subsidence of the area caused preferable vertical circulation of groundwater along the clastic dikes. In comparison with the surrounding rocks goethite-rich fluids have caused stronger cementation of clastic dikes during the post-dike history. Also some other minor diagenetic alternation processes took place in dikes.
\end{abstract}

Key words: fracturing, clastic dike, sandstones, Devonian, Estonia. 


\section{INTRODUCTION}

Clastic dikes are usually exotic phenomena in bedrock. In compressed sedimentary sequences they may yield specific essential information on the past geological processes that have taken place during the sedimentary breaks. In Baltoscandia, clastic dikes are considerably rare structures in sedimentary sequences and the uppermost parts of the crystalline basement.

Sedimentary clastic dikes are formed due to filling of open fractures with allogenic detrital material either on land or in sub-bottom layers of water bodies. Open fractures may be of tectonic or any other origin (e.g. compaction, landslides, etc.) in a rock massif subjected to extension or strike-slip movements. Usually filling of fractures soon follows their opening. In fact, filling of these fractures is a specific kind of infracrustal sedimentation in near-surface environments. The filling material was provided either from the Earth's surface or from suspension in the covering water body, from fracture walls or from loose layers of the sequence cross-cut by the fracture. Sedimentary structures (bedding types, etc.) may carry information on within-fracture sedimentation either above or under groundwater level. Clastic dikes may have developed either soon after the formation of the surrounding sediments or after some long period. From the moment of filling of fractures, sedimentary dikes and the surroundings have common diagenesis history. However, clastic dikes differing from the surroundings in water permeability may differ in the intensity of respective mineralizations.

In northern Baltoscandia, clastic dikes are met in different-age formations from Precambrian to Devonian. Sedimentary clastic dikes in the Precambrian crystalline basement, representing mainly NE-SW-trending tectonic fractures once open but afterwards filled with Cambrian sandstone, are reported from Baltic coastal areas in SW Finland and eastern Sweden (Bergman 1982; Tynni 1982). In the Ordovician carbonate sequence of North Estonia numerous clastic dikes have been found and described (Orviku 1960; Heinsalu \& Andra 1975). These dikes are filled with sandy material and strongly cemented by diagenetic pyrite and carbonates. The clastic dikes in the Precambrian basement and Middle Ordovician layers are related to regional sets of fractures in bedrock, mainly of NE-SW direction. The mode of occurrence and processes of formation are, however, specific at each site. The number of Devonian dikes recently found is considerably small. They are observed only in a restricted area of southeastern Estonia where sandstones of the Lode Member of the Gauja Formation are exposed (Fig. 1A). In the early 1990s we observed and documented a NW-SE-trending clastic dike of sandy and muddy composition in Piusa quarry. T. Pani explored the whole $500 \mathrm{~m}$ long and 150-200 m wide quarry where six clastic dikes were recorded (Fig. 1B; Pani \& Mark-Kurik 1995). Recently, Piusa quarry has been a popular subject of geological observations (Sõstra 1997). Our study deals with the composition of the Devonian clastic dikes, which is significant for the estimation of their age and possible origin. Laboratory investigations of the sample collection were carried out. 

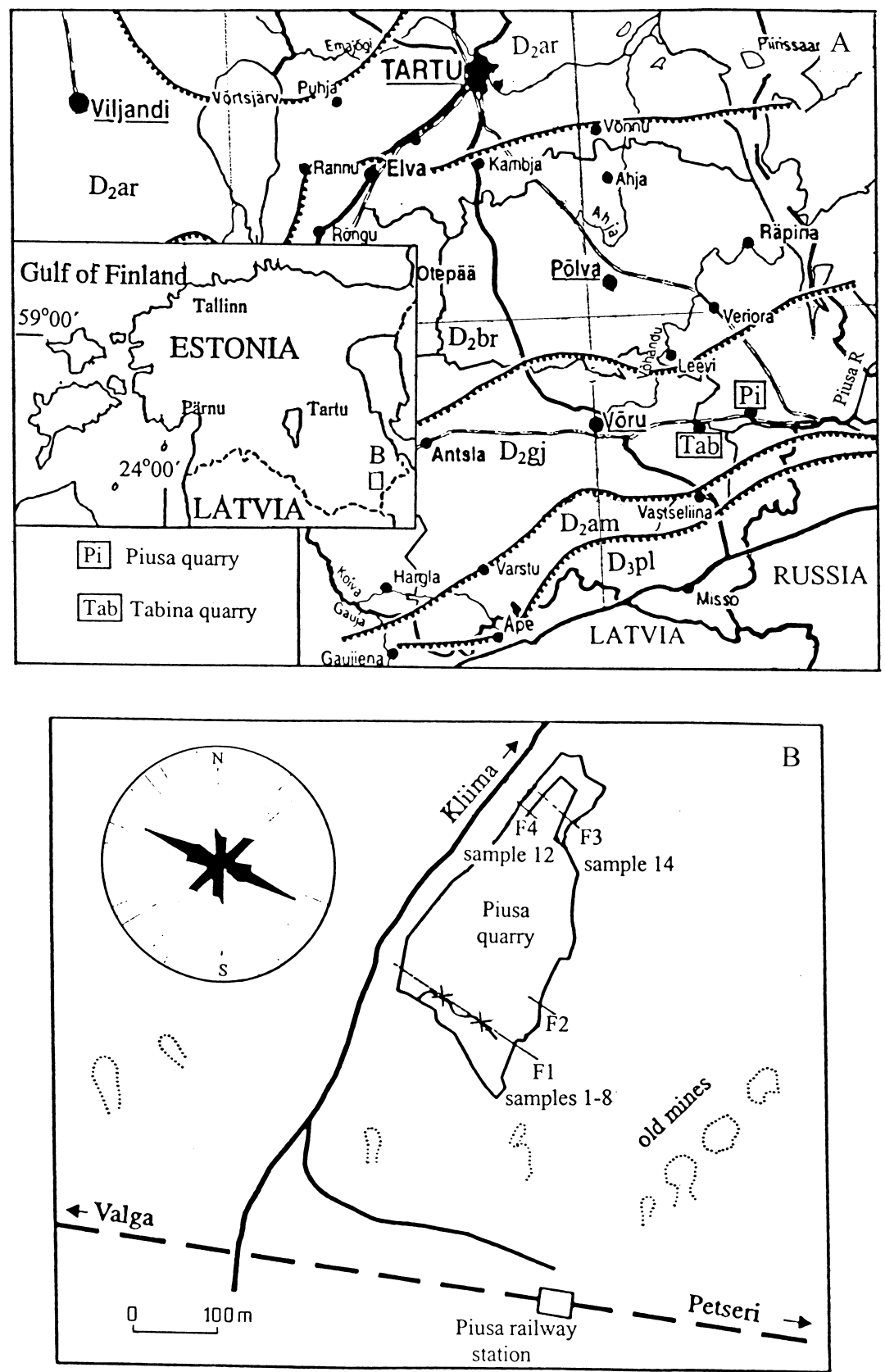

Fig. 1. (A) Location of Piusa (Pi) and Tabina (Tab) quarries. Outcrops of Devonian stages in southeastern Estonia: $\mathrm{D}_{2}$ ar, Aruküla; $\mathrm{D}_{2}$ br, Burtnieki; $\mathrm{D}_{2} \mathrm{gj}$, Gauja; $\mathrm{D}_{2} \mathrm{am}$, Amata; $\mathrm{D}_{3}$ pl, Plavinas. (B) Location of Piusa quarry with studied open fractures F1-F4. The rose diagram shows the direction of all measured fractures in the quarry. Crosses mark the fragments of fracture F1 discovered in the southern wall in 1990. 


\section{GEOLOGICAL SETTINGS}

Devonian sandstones and carbonate rocks are widely spread in the middle and western parts of the East European Craton. In southern Estonia ENE-WSWtrending stripes of Middle Devonian sandstone layers of the Pärnu, Narva, Aruküla, Burtnieki, Gauja, and Amata formations are exposed. In the SE corner of Estonia Upper Devonian dolomitic marlstones occur (Fig. 1; Kajak 1997; Kleesment \& Mark-Kurik 1997). Fracturing of Devonian sandstones is widespread, but not so frequent as in pre-Devonian carbonate rocks. Closed unfilled joints prevail (Miidel 1982; Kleesment \& Pirrus 2000; Pirrus at al. 2002). Filled fractures clastic dikes - have been found in sandstones of the Gauja Formation in Piusa (Fig. 1B) and neighbouring Tabina sandstone pits only. No vertical displacements are observed in connection with the dike-bearing fractures.

The maximum thickness of the Gauja Formation is about $80 \mathrm{~m}$. The formation is dominated by weakly to medium-cemented light to yellowish-grey, rarely light brown, pinkish-brown or variegated fine-grained cross-bedded sandstones. In the sequence of the formation two cyclic members can be distinguished. The lower complex, the Sietin Member, is mostly represented by sandstones with a layer of grey or variegated siltstone in its topmost part. The lower part of the thicker (50-60 m) upper complex, the Lode Member, consists of light, mainly white sandstones. Siltstones and clays dominate in its upper part. The Gauja Formation is overlain by the up to $30 \mathrm{~m}$ thick Amata Formation consisting of sandy-silty sediments alternating with frequent clay interbeds. The Amata Formation is overlain by the dolomitic complex of the Upper Devonian Plavinas Formation; (Kleesment 1995; Kajak 1997; Kleesment \& Mark-Kurik 1997).

The Lode time of the Gauja age was the phase of maximum Middle Devonian regression in the area under consideration. Subaqueous and subaerial delta plains alternated during this time, reflecting near-shore environments of retreating sea. Evidences of gradually changing depositional environments are imprinted into the sandstone sequence. Lenticular goethite-enriched interlayers of conglomerate often occur, in which clasts of siltstone and silty claystone are enclosed into sandy matrix. The high maturity of mineralogical composition and high content of kaolinite in mud fraction hints at the processes of subaerial weathering in the source area (Kuršs 1992; Kleesment 1995, 1997; Plink-Björklund \& Björklund 1999).

The clastic dike-bearing Lode Member is exposed in large Piusa and Tabina quarries and in the banks of the Piusa River valley between these quarries (Fig. 1A). The $12 \mathrm{~km}$ long section displays 17 natural high scarps with a total length of about $900 \mathrm{~m}$. The frequency of fractures in these rocks is considerably higher than in the underlying Devonian complexes (Kleesment \& Pirrus 2000). On average, a fracture was observed in each $2.8 \mathrm{~m}$. Two joint systems (striking WWN-EES and NNE-SSW) dominated. A few synclinal deformations occur there as well (Fig. 2A). Gauja sandstone beds are slightly dislocated also in river banks. A few local faults show throws up to $20 \mathrm{~cm}$. These are within-formational dislocations, covered with intact horizontal beds, and are probably caused by early compaction of sediments. 

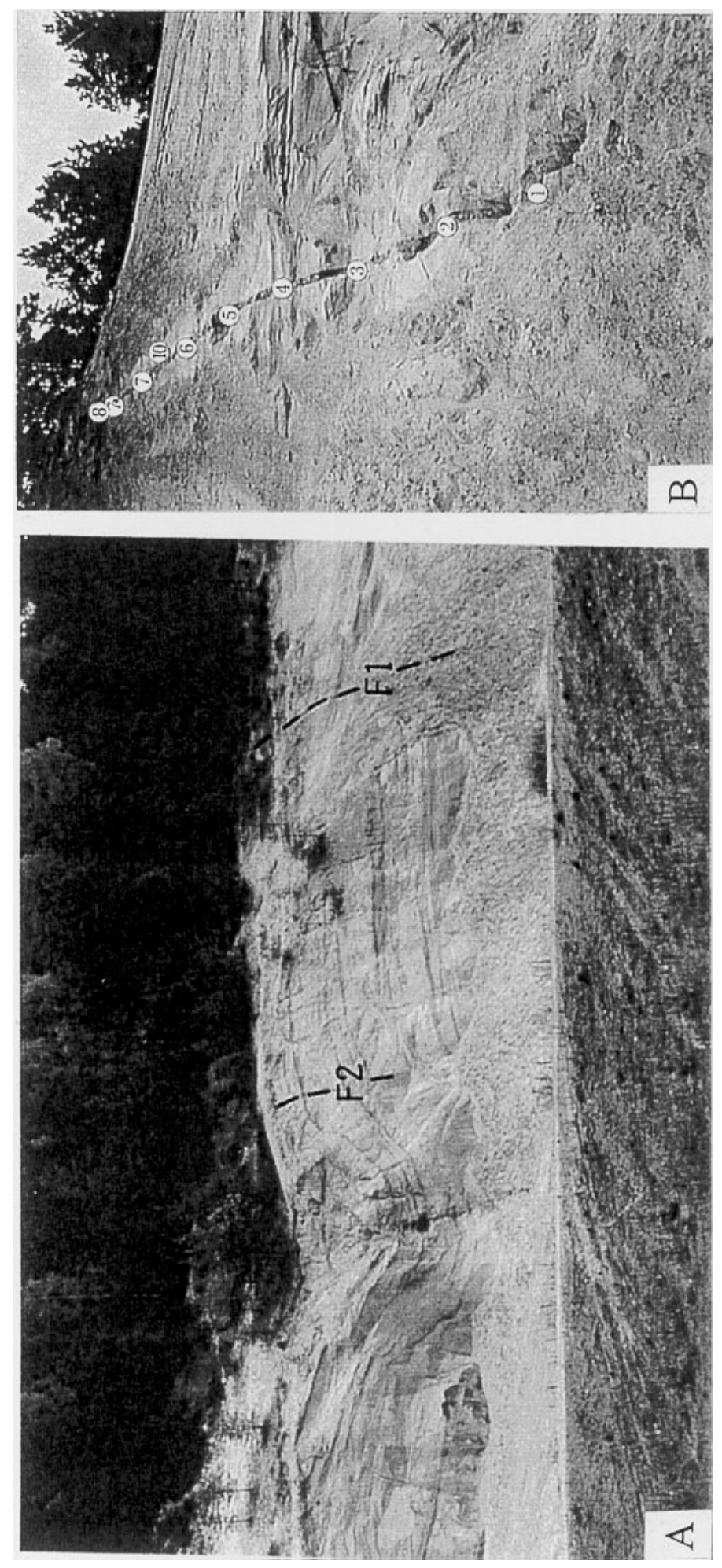

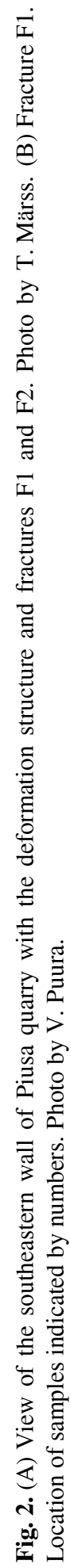


The Piusa-Tabina area is located within the SE marginal zone of the gentle slope of the Fennoscandian Shield where the sedimentary cover forms a uniform Estonian Homocline (Puura \& Vaher 1997). The dipping of bedding planes is around 15". However, the location is very near or within the marginal zone of the Haanja-Petseri branch of cupola-type anticlinal structures, which belong to the regional LiepajaRiga-Pskov system of Late Caledonian compressional dislocations (Indans 1962; Kaplan \& Hasanovitch 1969; Puura \& Vaher 1997). Those were recurrently activated during the Devonian (Suveizdis 1979; Vaher et al. 1980; Puura \& Vaher 1997).

\section{FIELD OBSERVATIONS AND SAMPLING}

In walls of $500 \mathrm{~m}$ long and up to $200 \mathrm{~m}$ wide Piusa quarry about 100 fractures were measured. Most of them are closed. Fractures trending NW-SE and steeply dipping NE dominate. Meridional $(\mathrm{N}-\mathrm{S})$ and NE-SW trending fractures are less numerous (Fig. 1B). In most cases they dip $60^{\circ}$ to $90^{\circ}$ towards NW or NE. Among closed fractures, least numerous are SW and SE dipping fractures. Observation of fractures in quarries is hampered by talus, hiding large areas of walls. In 1990 a clastic dike was discovered at two sites of the southern wall of Piusa quarry (Fig. 1B). In 1995-2001, filled fractures F1-F4 (Figs. 1B, 2B, 3A) and a single similar dike (Fig. 3B) were observed and sampled in Piusa and Tabina, respectively.

Clastic dike 1 as the most representative structure (Figs. 1B and 2) was carefully cleaned and described in 1995. Its best $7 \mathrm{~m}$ high exposure is located in the southeastern wall of Piusa quarry and trends in the direction $\mathrm{NW} 300^{\circ}$ at a dip of $84^{\circ}$ to SW. In 1990 the horizontal extent of the southern surface was fragmentarily observable along the southern wall of the quarry, stretching for about $100 \mathrm{~m}$ (Fig. 1B). The 9.5-10 cm wide dike is composed of sandy material consisting of abundant clasts of sandstone, siltstone, and claystone, resembling the rocks of the Gauja Formation. No stratification was found in the dike. The dike attracts attention by its rusty-brown pigmentation and stronger cementation rate than in the surrounding rocks. The fracture walls are covered with goethite film. Samples (Pi1-Pi7a) were taken from every metre of the dike. Reference samples from the Gauja Formation (Pi11, Pi13), outcropping in the quarry walls, and from the overlying Quaternary deposits (Pi8) were also collected (Fig. 2B, Tables 1-6).

Clastic dike 2 composed of sandy material is exposed in the uppermost $1.5 \mathrm{~m}$ of the quarry wall, $60 \mathrm{~m}$ northeast of F1 (F2; Figs. 1B and 2A). The $10 \mathrm{~cm}$ wide dike trends in the direction NW $300^{\circ}$ at a dip of $86^{\circ} \mathrm{NE}$. No bedding structures were found.

Clastic dikes F1 and F2 are located in the SE side of a small synclinal structure, which is about $4 \mathrm{~m}$ deep and $40 \mathrm{~m}$ wide (Fig. 2A). Its axial plane trends in the direction WNW $285^{\circ}$ at a dip of $75^{\circ} \mathrm{SW}$. The syncline is roughly parallel to fractures F1 and F2. A horizontal layer of Quaternary deposits rests on the top of the almost smooth bedrock.

Clastic dike 3 is exposed in the northern part of the NE wall of the quarry (F3; Fig. 1B). Trending in the direction NW $297^{\circ}$ at a dip of $88^{\circ} \mathrm{SW}$, it consists of two parallel thin dikes $1-3 \mathrm{~cm}$ wide. The filling is clayey silty and sandy 
material, abundantly impregnated with goethite (Fig. 3A). The goethite films on the fracture walls are uneven. The observable vertical extent of this clastic dike is $4 \mathrm{~m}$. On the opposite wall of the quarry a closed vertical fracture of the same direction was discovered (Fig. 1B).

Clastic dike 4 was found in the northwestern wall of the quarry. It trends in the direction NW $320^{\circ}$ (F4; Fig. 1B) and its observable vertical reach is $5 \mathrm{~m}$. The $5 \mathrm{~cm}$ wide fracture is filled with unbedded silty sandstone containing abundant small angular clayey-silty clasts. The fracture filling is relatively strongly cemented compared to the surrounding sandstone in the quarry wall.

In Tabina quarry (Fig. 1A), numerous closed fractures cut the wall. In the eastern wall of the quarry only a single clastic dike was found. It trends in the direction WNW $280^{\circ}$ at a dip of $85^{\circ} \mathrm{NE}$. Its observable vertical reach is about $4 \mathrm{~m}$. The $8 \mathrm{~cm}$ wide fracture is filled with loose sandstone. The northern surface of the fracture is even, the southern surface slightly uneven. The fracture walls have only a very poor goethite pigmentation, whereas in the fracture filling goethite is a significant component. In the upper part of the exposure, a syncline-like deformation of sandstone beds is observed (Fig. 3B).

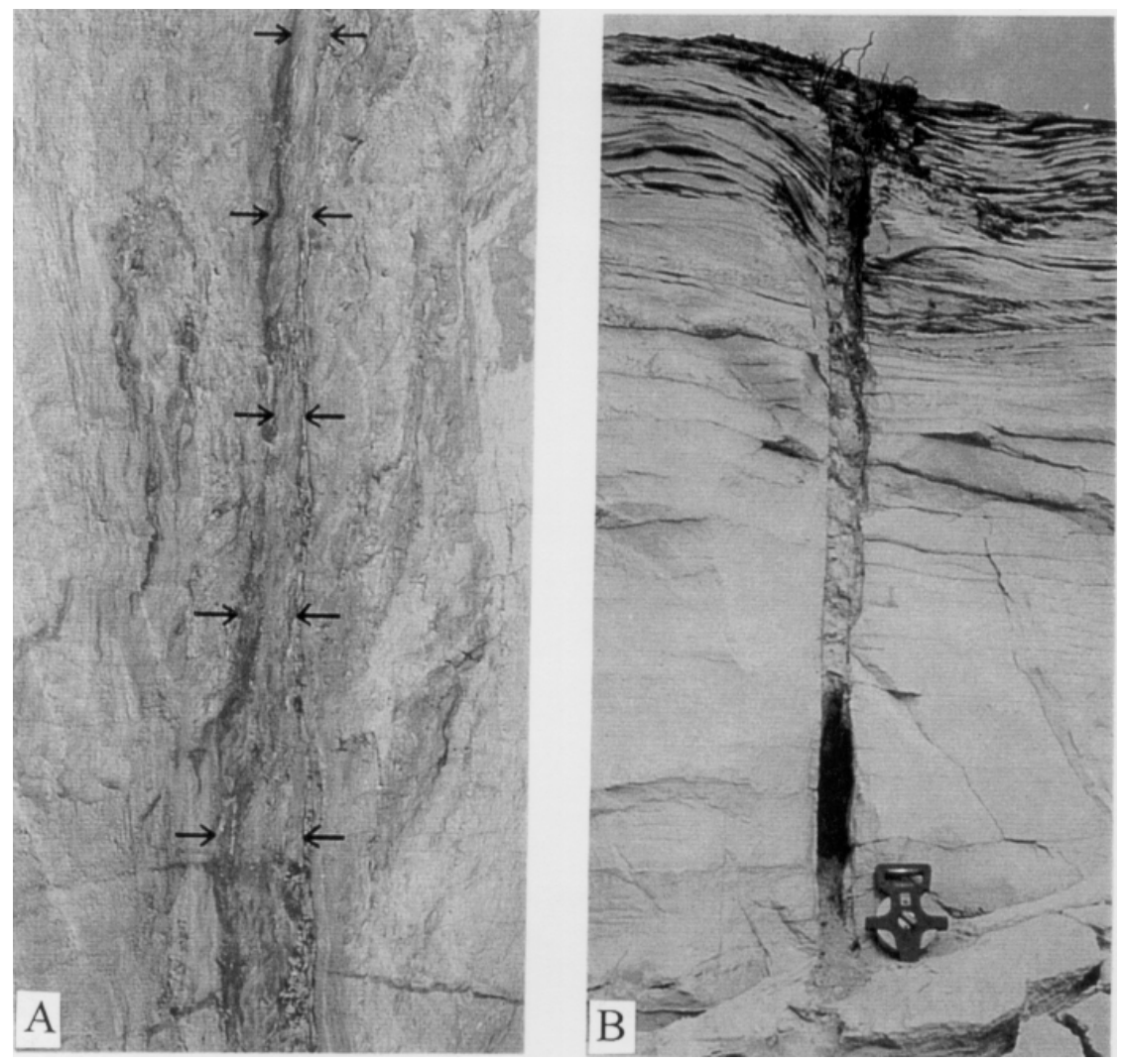

Fig. 3. (A) View of the central part of fracture F3 in Piusa quarry. The fracture is marked by arrows. Photo by Ü. Sõstra. (B) View of the open fracture in Tabina quarry. Photo by E. Pirrus. 
This syncline is due to thinning of a sandstone bed $1 \mathrm{~m}$ down from the top of the bedrock. The material of this layer near the open fracture has fallen into the fracture.

\section{LABORATORY TECHNIQUES}

Grain size spectrum of the clastic and detrital material was studied in laboratory using sieving. The mineralogical composition of fractions of samples was determined by means of optical microscopy and X-ray diffraction. The grain size distribution of both the dike and surrounding sandstone, matrix of the clastic dike and disintegrated clasts separated from the dike sandstone, and the content of clasts in dikes were studied (Tables 1-3). Clasts were carefully separated from poorly and moderately cemented samples and studied (Fig. 4A). In some cases sandy clasts with predominantly kaolinite cement, sandy clasts with kaolinitegoethite cement, and clasts from clayey silt were separately analysed (Table 2). Soft clasts of some samples were crumbled to the matrix by laboratory works and the clastic dike was investigated in total (Table 1, samples Pi1 and Pi12). Separated clasts were fractionated using sieves with diameters of 10, 7, 5, 3, and $2 \mathrm{~mm}$. From the $<2 \mathrm{~mm}$ fraction mud $(<0.01 \mathrm{~mm})$ was removed by washing. The grain size interval of $2-0.01 \mathrm{~mm}$ was separated by sieving into $2.0-1.0,1.0-0.5$,

Table 1. Lithological composition of samples from fracture fillings

\begin{tabular}{l|c|c|c|c|c|c|c|c}
\hline $\begin{array}{c}\text { Sample } \\
\text { No. }\end{array}$ & $\begin{array}{c}\text { Content of } \\
\text { clasts, } \%\end{array}$ & \multicolumn{7}{c}{ Grain size $(\mathrm{mm})$ distribution of matrix, \% } \\
\cline { 3 - 8 } Pi1 & $2-1$ & $1-0.5$ & $0.5-0.25$ & $0.25-0.1$ & $0.1-0.05$ & $0.05-0.01$ & $<0.01$ \\
Pi2 & Decomposed & 0.1 & 0.6 & 11.7 & 61.3 & 9.8 & 4.9 & 11.6 \\
Pi3 & 26.7 & - & 0.4 & 17.1 & 62.3 & 9.7 & 2.5 & 8.0 \\
Pi4 & 16.8 & - & 0.3 & 12.3 & 69.6 & 10.8 & 3.4 & 3.6 \\
Pi5 & 53.6 & & & & Not analysed & & \\
Pi6 & 18.0 & $<0.1$ & 0.3 & 11.0 & 67.4 & 11.9 & 3.5 & 5.9 \\
Pi7 & 28.5 & $<0.1$ & 0.3 & 6.9 & 61.0 & 16.4 & 5.7 & 9.7 \\
Pi7a & 43.2 & & & & Not analysed & & \\
Pi8 & 70.6 & 0.3 & 1.5 & 7.5 & 46.5 & 18.6 & 10.5 & 15.1 \\
Pi12 & 59.6 & 3.0 & 8.4 & 33.5 & 43.6 & 6.2 & 2.0 & 3.3 \\
Pi14 & Decomposed & 0.1 & 0.6 & 5.2 & 24.1 & 14.3 & 25.3 & 30.4 \\
Tab1 & 2.7 & 0.3 & 0.5 & 4.5 & 15.4 & 10.8 & 10.1 & 58.4 \\
& Absent & - & 1.3 & 23.5 & 60.6 & 9.5 & 2.0 & 3.1
\end{tabular}

$\mathrm{Pi}$, samples from Piusa quarry; Tab, Tabina quarry. 
Table 2. Grain size (mm) distribution of decomposed clasts from fracture F1 of Piusa (Pi) quarry

\begin{tabular}{|c|c|c|c|c|c|c|c|c|}
\hline \multirow{2}{*}{$\begin{array}{c}\text { Sample } \\
\text { No. }\end{array}$} & \multirow{2}{*}{$\begin{array}{l}\text { Character } \\
\text { of clasts }\end{array}$} & \multicolumn{7}{|c|}{ Distribution, $\%$} \\
\hline & & $>1$ & $1-0.5$ & $0.5-0.25$ & $0.25-0.1$ & $0.1-0.05$ & $0.05-0.01$ & $<0.01$ \\
\hline $\mathrm{Pi} 3 \mathrm{c}$ & All clasts & - & - & 4.2 & 28.9 & 15.0 & 20.3 & 31.6 \\
\hline Pi3csk & White sandstone & - & $<0.1$ & 2.7 & 30.6 & 36.1 & 23.4 & 7.2 \\
\hline Pi3csg & $\begin{array}{l}\text { Sandstone with } \\
\text { goethite }\end{array}$ & - & $<0.1$ & 7.7 & 42.4 & 27.0 & 15.5 & 7.4 \\
\hline $\mathrm{Pi} 4 \mathrm{cc}$ & Clayey silt & $<0.1$ & 0.1 & 1.0 & 8.0 & 12.6 & 21.7 & 56.5 \\
\hline Pi6csk & White sandstone & - & $<0.1$ & 7.8 & 36.0 & 25.8 & 20.7 & 9.8 \\
\hline Pi6csg & $\begin{array}{l}\text { Sandstone with } \\
\text { goethite }\end{array}$ & - & $<0.1$ & 7.0 & 44.4 & 24.0 & 13.7 & 9.9 \\
\hline Pi6cc & Clayey silt & $<0.1$ & $<0.1$ & 1.0 & 7.6 & 13.2 & 25.1 & 53.1 \\
\hline Pi7a c & All clasts & 0.2 & 0.2 & 1.3 & 9.6 & 7.7 & 7.3 & 73.7 \\
\hline
\end{tabular}

Letters by sample numbers denote: c, all clasts; csk, sandstone clasts with kaolinite cement; csg, sandstone clasts with goethite-kaolinite cement; cc, clasts of clayey silt.

Table 3. Grain size (mm) distribution of bedrock in studied locations

\begin{tabular}{|c|c|c|c|c|c|c|c|c|}
\hline \multirow{2}{*}{$\begin{array}{c}\text { Sample } \\
\text { No. }\end{array}$} & \multirow{2}{*}{ Sample location } & \multicolumn{7}{|c|}{ Distribution, $\%$} \\
\hline & & $>1$ & $1-0.5$ & $0.5-0.25$ & $0.25-0.1$ & $0.1-0.05$ & $0.05-0.01$ & $<0.01$ \\
\hline Pi10 & Pocket near F1 & 0.7 & 0.2 & 1.9 & 11.0 & 4.9 & 12.6 & 69.4 \\
\hline Pi11 & Sandstone from quarry wall & - & 0.1 & 2.3 & 89.7 & 6.7 & 0.3 & 0.9 \\
\hline Pi13 & Clayey siltstone from wall & - & 0.5 & 2.3 & 5.0 & 17.3 & 21.7 & 53.1 \\
\hline Pi128 & $\begin{array}{l}\text { Sandstone from mine } \\
\text { nearby }\end{array}$ & - & 2.9 & 31.1 & 49.3 & 15.0 & 0.9 & 0.8 \\
\hline Pi129 & $\begin{array}{l}\text { Sandstone from mine } \\
\text { nearby }\end{array}$ & - & 2.5 & 32.2 & 50.8 & 13.5 & 0.6 & 0.4 \\
\hline Pi130 & $\begin{array}{l}\text { Sandstone from mine } \\
\text { nearby }\end{array}$ & - & 0.1 & 6.6 & 77.5 & 14.6 & 0.6 & 0.6 \\
\hline Pi131 & $\begin{array}{l}\text { Sandstone from mine } \\
\text { nearby }\end{array}$ & - & 1.3 & 28.9 & 48.1 & 18.6 & 2.3 & 0.8 \\
\hline Pi132 & $\begin{array}{l}\text { Sandstone from mine } \\
\text { nearby }\end{array}$ & - & 0.8 & 15.2 & 75.4 & 7.6 & 0.8 & 0.2 \\
\hline Pi133 & $\begin{array}{l}\text { Sandstone from mine } \\
\text { nearby }\end{array}$ & - & 1.2 & 49.9 & 43.8 & 4.9 & 0.1 & 0.1 \\
\hline Tab21 & Sandstone from quarry wall & - & 0.2 & 11.2 & 80.1 & 5.2 & 3.3 & \\
\hline Tab22 & Sandstone from quarry wall & $<0.1$ & 0.7 & 21.4 & 71.5 & 3.5 & 2.9 & \\
\hline Tab23 & Sandstone from quarry wall & - & $<0.1$ & 3.2 & 76.0 & 16.1 & 4.6 & \\
\hline Tab24 & Sandstone from quarry wall & 0.3 & 5.0 & 42.1 & 47.6 & 2.7 & 2.3 & \\
\hline Tab25 & Sandstone from quarry wall & $<0.1$ & 1.0 & 27.1 & 67.5 & 2.3 & 2.1 & \\
\hline
\end{tabular}

Pi, Piusa quarry; Tab, Tabina quarry. Data on samples Tab21-25 from Sinisalu (1997). 

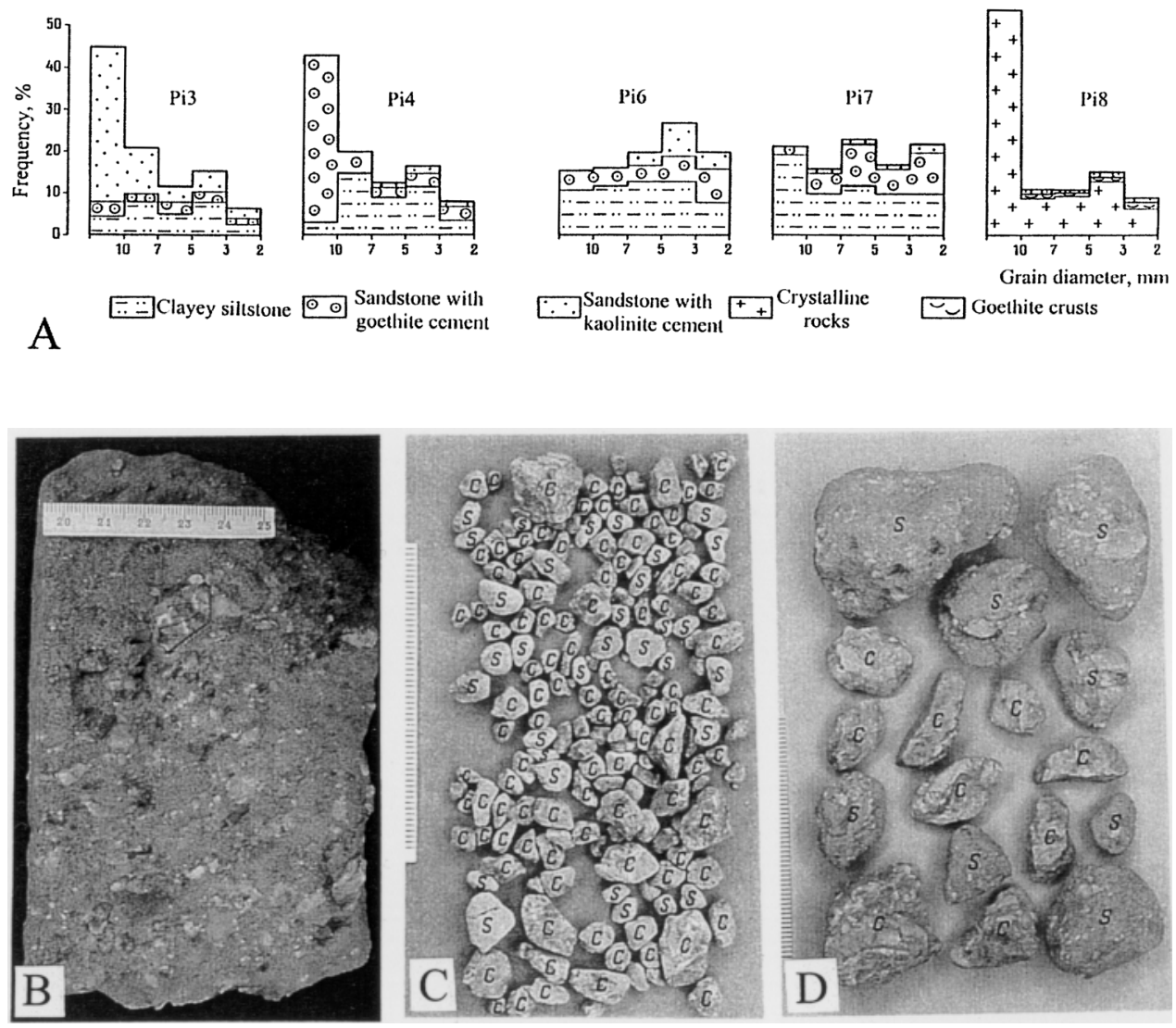

Fig. 4. The content (A) and character of clasts in fracture F1 of Piusa quarry. (B) Comparatively strongly cemented part of fracture filling between samples 4 and 5. (C) Clasts separated from sample 4. (D) Clasts of sample 6, grain size class coarser than $10 \mathrm{~mm}$. Sandstone clasts contain particles of clayey silt. Letters on C and D: s, sandstone clast; c, clayey silty clast. Photos by G. Baranov. For location of samples see Fig. 2.

$0.5-0.25,0.25-0.1,0.1-0.05$, and $0.05-0.01 \mathrm{~mm}$ fractions. The three coarsest fractions were investigated using binocular optical microscope. The $0.1-0.05 \mathrm{~mm}$ fraction was further separated and classified using bromoform. Heavy and light minerals were determined in immersion liquids under a microscope in plane-polarized transmitted light. About 300-500 mineral grains were counted in each mineral spectrum and the results were expressed as percentages (Tables 4-6).

The mineralogical composition of muddy particles $(<0.01 \mathrm{~mm})$ in clastic dikes was studied by X-ray diffraction using HZG4 diffractometer (Fe filtered Co radiation). Sample powder was mixed with alcohol and spread on the glass slide 
(slurry mounts were prepared). For identification of the main minerals a range from $5^{\circ}$ to $40^{\circ} 2 \theta$ was step-scanned (step size $0.05^{\circ} 2 \theta$, counting rate $3 \mathrm{~s}$ ).

In mud fraction also trace elements were examined by X-ray fluorescence using the equipment VRA-30 (X-ray tube Fe filtered Co radiation, with Mo anode at $50 \mathrm{kV}$ and $15 \mathrm{~mA}$ ). Peak/background ratios were used for calibration. The precision of analysis was estimated as follows: $5 \mathrm{ppm}$ for $\mathrm{U}, \mathrm{Th}, \mathrm{Pb}, \mathrm{Y}$, $\mathrm{Sr}, \mathrm{Rb}, \mathrm{Br}, \mathrm{Se}$, and $\mathrm{As} ; 10 \mathrm{ppm}$ for $\mathrm{Zn}$ and $\mathrm{Ni} ; 50 \mathrm{ppm}$ for $\mathrm{Mn}$; and $0.3 \%$ for $\mathrm{Fe}_{2} \mathrm{O}_{3}$.

\section{RESULTS OF LABORATORY STUDIES}

\section{Lithology of clastic dikes}

Out of four clastic dikes sampled, the most detailed information was obtained from dike F1, from which 10 samples were analysed (Figs. 2B, 4; Tables 1, 2, 4-6). Dike F1 consists mainly of fine-grained quartz sand that contains abundant clasts of random orientation (Fig. 4B). The main character of the matrix is similar to the surrounding rocks. A comparatively high content of the muddy component is due to decomposition of clayey-silty clasts (Tables 1 and 3). The content of clasts in the dike varies between 16.6 and 70.6\% (Table 1). Poorly sorted isolated clasts did not reveal any internal stratification (Fig. 4B). The diameter of clasts ranges from 2 to $40 \mathrm{~mm}$. Sandy matrix contains also angular particles of clayey silt finer than $2 \mathrm{~mm}$. Angular clasts of variegated clayey siltstone occur together with sub-rounded and rounded clasts of sandstone (Fig. 4C, D). Part of the sandstone clasts contain kaolinite-goethite cement and are pigmented. Part of the clasts are white, having mainly kaolinitic cement only with a little admixture of goethite. Sandstone clasts with goethitic cement are slightly coarser than the white clasts (Table 2). Relatively coarse white sandstone clasts occur in the lower part of the clastic dike. Upwards the amount of clasts of clayey silt increases (Fig. 4A). In the upper part of the dike coarser sandstone clasts often contain small angular particles of clayey silt (Fig. 4D). Host of the clastic dike is weakly cemented except $1 \mathrm{~m}$ between samples Pi4 and Pi5 (Fig. 1B), which is moderately cemented. Mainly kaolinite-illite cement contains also goethite and a small amount of gypsum (Fig. 5).

Clastic dike F4 is composed of relatively strongly cemented very fine sandstone, containing abundant angular clasts of variegated clayey silt with chaotic orientation. The diameter of the clasts varies from 2 to $20 \mathrm{~mm}$. The grainsize composition of the filling material corresponds to the mixed silty-sandy sediment (Table 1, sample 12). The fracture in Tabina quarry was filled with loose sandstone.

As a whole, in clastic dikes of the studied quarries only fillings with no evidences of water transport-related stratification structures were found. It suggests that the fracture fillings found in Piusa and Tabina quarries were formed above the groundwater level. 
Table 4. Mineral composition (\%) of studied samples. Light minerals of grain size class $0.1-0.05 \mathrm{~mm}$

\begin{tabular}{|c|c|c|c|c|c|c|c|c|c|c|}
\hline $\begin{array}{c}\text { Sample } \\
\text { No. }\end{array}$ & 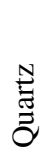 & 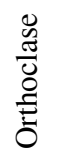 & $\begin{array}{l}0 \\
\frac{0}{0} \\
\frac{\pi}{0} \\
\frac{0}{00} \\
\frac{\pi}{2}\end{array}$ & 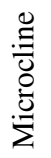 & 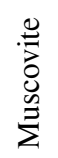 & 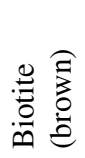 & 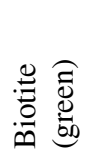 & 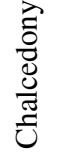 & 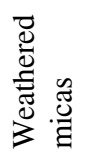 & 忢 \\
\hline
\end{tabular}

\begin{tabular}{llllccccccc}
\hline & \multicolumn{8}{c}{ Matrix of fracture fillings } \\
Pi1 & 89.3 & 7.4 & 0.3 & - & 0.7 & - & 2.0 & 0.3 & - & - \\
Pi2 & 94.0 & 3.9 & 0.6 & 0.3 & 0.3 & - & 0.3 & 0.6 & - & - \\
Pi3 & 94.0 & 4.5 & 0.3 & - & 0.9 & - & 0.3 & - & - & - \\
Pi5 & 93.7 & 2.7 & 0.9 & - & 1.5 & - & 0.3 & 0.6 & - & 0.3 \\
Pi6 & 92.5 & 6.3 & 0.3 & 0.9 & - & - & - & - & - & - \\
Pi7a & 91.9 & 4.5 & 0.6 & 0.3 & 2.1 & - & 0.6 & - & - & - \\
Pi8 & 80.9 & 5.7 & 0.9 & - & - & 12.2 & 0.3 & - & - & - \\
Pi12 & 67.6 & 5.3 & 0.3 & 0.3 & 12.2 & 0.6 & 13.7 & - & - & - \\
Pi14 & 90.8 & 5.1 & 0.8 & - & 2.5 & 0.8 & - & - & - & - \\
Tab1 & 89.0 & 8.0 & 0.6 & - & 2.1 & - & - & 0.3 & - & - \\
& & & & & & & & & &
\end{tabular}

\begin{tabular}{lllllclllll} 
& \multicolumn{8}{c}{ Clasts } \\
Pi3c & 96.7 & 2.7 & - & - & 0.3 & - & - & 0.3 & - & - \\
Pi3csk & 94.4 & 4.7 & - & - & - & - & 0.9 & - & - & - \\
Pi3csg & 97.3 & 1.2 & 0.3 & 0.6 & 0.3 & - & 0.3 & - & - & - \\
Pi4cc & 92.6 & 3.4 & 0.3 & - & 0.3 & - & 3.4 & - & - & - \\
Pi6csk & 97.0 & 2.4 & - & - & 0.3 & - & 0.3 & - & - & - \\
Pi6csg & 97.3 & 2.4 & - & - & - & - & 0.3 & - & - & - \\
Pi6cc & 96.1 & 2.1 & - & - & 0.3 & - & 1.5 & - & - & - \\
Pik7a c & 93.2 & 3.7 & - & 0.1 & 1.3 & - & 1.7 & - & - & -
\end{tabular}

\begin{tabular}{lccccccccccr} 
& \multicolumn{8}{c}{ Surrounding bedrock } \\
Pi10 & 89.5 & 4.2 & - & - & 0.6 & 0.9 & 4.8 & - & - & - \\
Pi11 & 93.9 & 4.9 & 0.3 & - & 0.3 & - & - & 0.3 & 0.3 & - \\
Pi13 & 16.8 & 2.8 & - & - & 38.8 & 0.3 & 41.3 & - & - & - \\
Pi128 & 97.8 & 2.0 & 0.2 & - & - & - & - & - & - & - \\
Pi129 & 97.2 & 2.8 & - & - & - & - & - & - & - & - \\
Pi131 & 98.5 & 1.5 & - & - & - & - & - & - & - & - \\
Pi132 & 91.1 & 7.8 & 0.3 & & 0.5 & - & 0.3 & - & - & - \\
Pi133 & 95.1 & 4.6 & - & 0.3 & - & - & - & - & - & - \\
Tab21 & 92.4 & 6.7 & - & - & 0.9 & - & - & - & - & - \\
Tab22 & 95.0 & 5.0 & - & - & - & - & - & - & - & - \\
Tab23 & 94.2 & 4.2 & - & - & 1.1 & & 0.5 & - & - & - \\
Tab24 & 83.6 & 13.9 & - & - & 2.0 & & 0.5 & - & - & - \\
Tab25 & 87.1 & 11.3 & - & - & 1.4 & & 0.2 & - & - & - \\
& & & & & & & & &
\end{tabular}

Location of samples from Piusa (Pi) quarry is shown in Figs. 1 and 2. Explanation of letters by clast sample numbers is given in Table 2 . The character and location of reference rocks are given in Table 3. Data on samples from Tabina quarry Tab21-Tab25 are from Sinisalu (1997). - not found. 
Table 5. Mineral composition (\%) of investigated samples. Heavy minerals of grain size class 0.1-0.05 mm

\begin{tabular}{|c|c|c|c|c|c|c|c|c|c|c|c|c|c|}
\hline $\begin{array}{c}\text { Sample } \\
\text { No. }\end{array}$ & 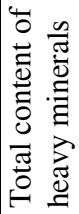 & 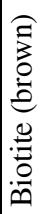 & 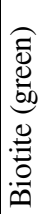 & 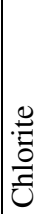 & 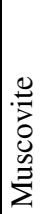 & 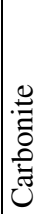 & 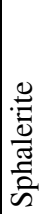 & 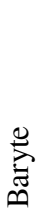 & 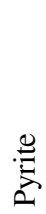 & 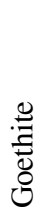 & 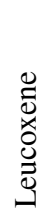 & $\begin{array}{l}\stackrel{\mathscr{U}}{\Xi} \\
\stackrel{\Xi}{\Xi} \\
\Xi\end{array}$ & 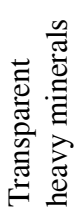 \\
\hline
\end{tabular}

\begin{tabular}{|c|c|c|c|c|c|c|c|c|c|c|c|c|c|}
\hline \multicolumn{14}{|c|}{ Matrix of fracture fillings } \\
\hline Pi1 & 0.44 & 0.6 & 0.9 & 0.6 & - & - & - & - & 0.2 & 16.0 & 9.6 & 37.8 & 32.8 \\
\hline $\mathrm{Pi} 2$ & 0.45 & - & 3.0 & 0.4 & - & 0.2 & - & - & - & 13.4 & 5.6 & 45.4 & 32.0 \\
\hline $\mathrm{Pi} 3$ & 0.73 & - & 0.4 & 0.2 & 0.4 & - & - & - & - & 7.0 & 5.2 & 48.4 & 38.4 \\
\hline $\mathrm{Pi} 5$ & 0.42 & - & 0.6 & 0.2 & - & - & - & - & - & 18.6 & 6.4 & 41.0 & 33.2 \\
\hline Pi6 & 0.17 & - & 0.6 & - & - & - & - & - & - & 15.8 & 13.4 & 43.4 & 26.8 \\
\hline Pi7a & 0.50 & - & 0.7 & 0.4 & - & - & - & - & - & 23.4 & 8.7 & 37.1 & 29.7 \\
\hline Pi8 & 3.80 & 1.2 & 4.0 & - & - & - & - & - & - & 11.4 & 1.0 & 19.3 & 63.1 \\
\hline Pi12 & 0.79 & $<0.1$ & 29.0 & 2.2 & 0.6 & - & - & - & - & 16.4 & 3.0 & 30.7 & 18.1 \\
\hline Pi14 & 0.70 & - & 1.0 & - & 0.4 & - & - & 0.6 & 16.2 & 19.6 & 3.2 & 37.0 & 22.0 \\
\hline Tab1 & 0.50 & 0.2 & 3.0 & 1.1 & - & - & - & 0.2 & 13.7 & 32.6 & 3.4 & 27.8 & 18.0 \\
\hline \multicolumn{14}{|c|}{ Clasts } \\
\hline $\mathrm{Pi} 3 \mathrm{c}$ & 0.42 & - & 5.0 & 0.6 & - & - & - & - & - & 26.4 & 9.6 & 38.0 & 20.4 \\
\hline $\mathrm{Pi} 3 \mathrm{csl}$ & 0.40 & $<0.1$ & 0.4 & 0.2 & $<0.1$ & $<0.1$ & - & - & 0.4 & 20.2 & 5.8 & 41.2 & 31.8 \\
\hline Pi3csg & 0.55 & 0.4 & 8.0 & 0.4 & - & - & - & - & 0.4 & 39.6 & 2.0 & 30.2 & 19.0 \\
\hline $\mathrm{Pi} 4 \mathrm{cc}$ & 2.80 & $<0.1$ & 6.4 & - & - & - & - & - & - & 80.8 & 3.8 & 4.4 & 4.6 \\
\hline Pi6csl & 0.48 & 0.2 & 0.4 & 0.2 & - & 0.2 & - & - & - & 19.2 & 25.2 & 32.8 & 21.8 \\
\hline Pi6csg & 0.50 & - & 1.4 & - & - & - & - & - & - & 29.4 & 11.6 & 36.2 & 21.4 \\
\hline Pi6cc & 5.60 & $<0.1$ & 1.2 & - & - & - & - & - & - & 85.2 & 2.8 & 6.8 & 4.0 \\
\hline Pi7a c & 1.10 & 0.2 & 3.3 & 0.4 & - & - & - & - & - & 60.4 & 10.7 & 13.4 & 11.6 \\
\hline \multicolumn{14}{|c|}{ Surrounding bedrock } \\
\hline Pi10 & 5.10 & $<0.1$ & 14.6 & - & - & - & - & - & - & 72.0 & 3.4 & 5.2 & 4.8 \\
\hline Pi11 & 0.67 & - & $<0.1$ & 0.2 & - & 0.4 & - & - & - & 1.8 & 7.2 & 55.4 & 35.0 \\
\hline Pi13 & 0.30 & 0.4 & 47.0 & 2.2 & 6.0 & $<0.1$ & - & 4.6 & - & 16.0 & - & 18.8 & 5.0 \\
\hline Pi128 & 0.10 & - & 0.7 & - & - & - & - & - & - & 1.8 & 7.4 & 64.5 & 25.6 \\
\hline Pi129 & 0.53 & - & 0.2 & - & - & - & - & - & - & 3.6 & 8.0 & 65.0 & 23.2 \\
\hline Pi131 & 0.87 & - & - & - & - & - & - & - & - & 11.3 & 8.5 & 60.7 & 19.5 \\
\hline Pi132 & 1.11 & - & 0.2 & - & - & - & - & - & - & 4.3 & 16.3 & 54.1 & 25.1 \\
\hline Pi133 & 1.38 & - & 0.2 & - & - & - & - & - & - & 14.7 & 8.5 & 51.8 & 24.8 \\
\hline Tab21 & 3.10 & - & - & - & 2.6 & 0.1 & - & - & - & 6.5 & 9.8 & 36.5 & 44.5 \\
\hline Tab22 & 2.90 & - & - & - & 1.1 & 0.1 & 0.1 & - & - & 14.1 & 15.0 & 22.2 & 47.4 \\
\hline Tab23 & 0.65 & - & - & - & 3.4 & - & - & - & - & 11.0 & 16.7 & 23.9 & 45.0 \\
\hline Tab24 & 1.79 & \multicolumn{2}{|c|}{0.8} & - & 1.7 & 0.1 & - & - & - & 15.4 & 11.4 & 29.0 & 41.6 \\
\hline Tab25 & 4.50 & \multicolumn{2}{|c|}{0.1} & - & 0.6 & - & - & 0.2 & - & 1.4 & 13.2 & 35.4 & 49.1 \\
\hline
\end{tabular}

Location of samples from Piusa (Pi) quarry is shown in Figs. 1 and 2. Explanation of letters by sample numbers is given in Table 2. The character and location of reference rocks are given in Table 3. Data on samples from Tabina quarry Tab21-Tab25 are from Sinisalu (1997). - not found. 


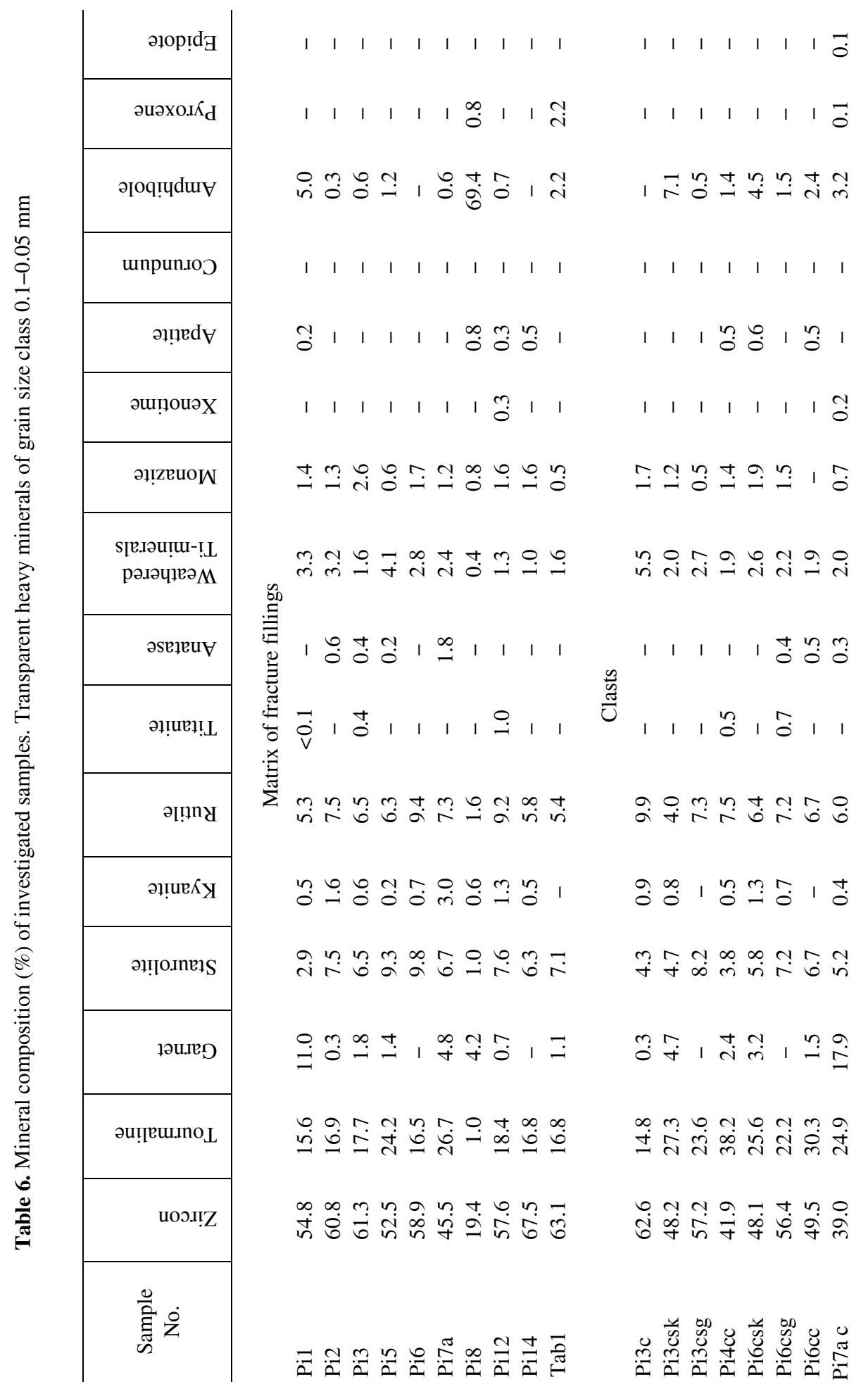




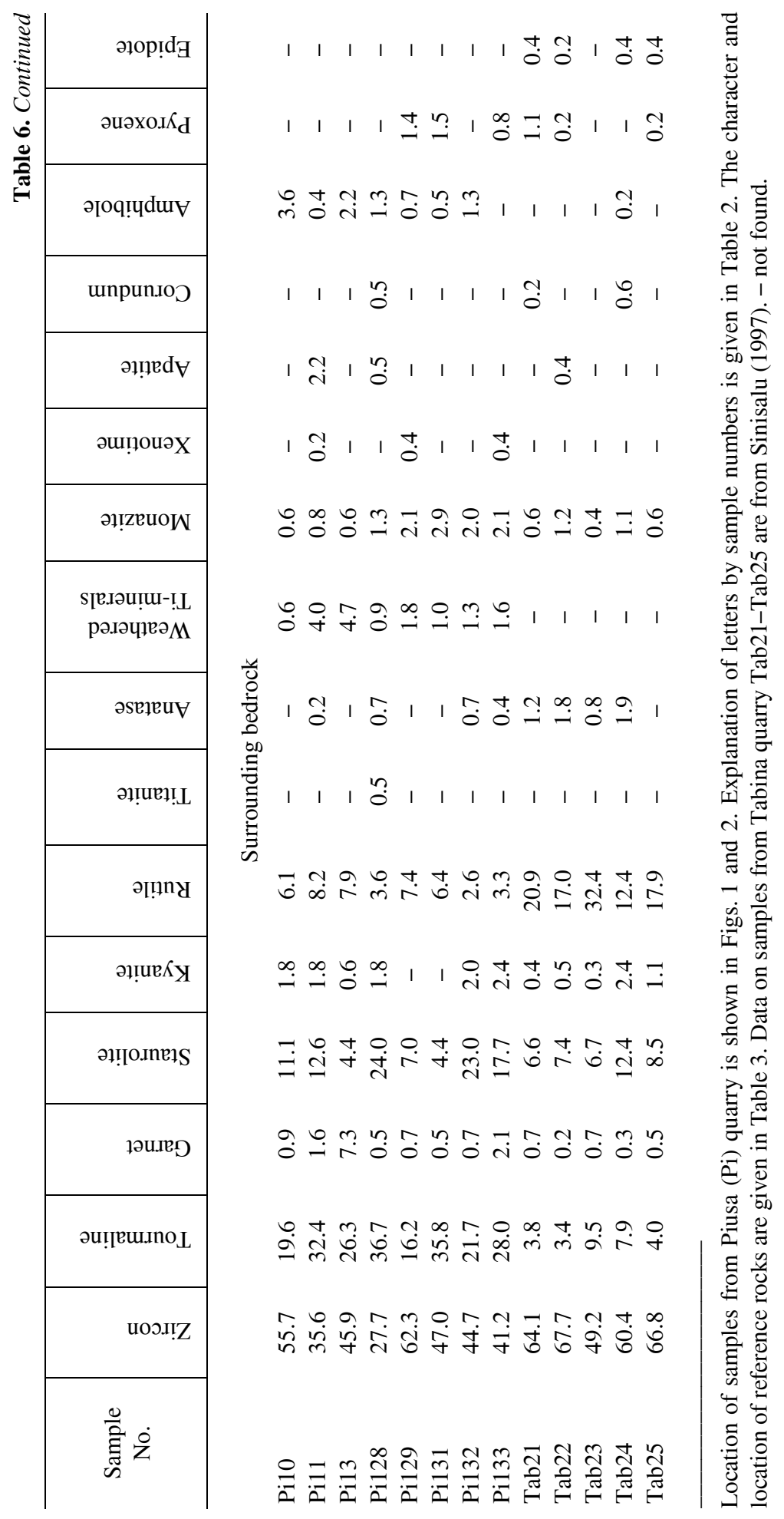




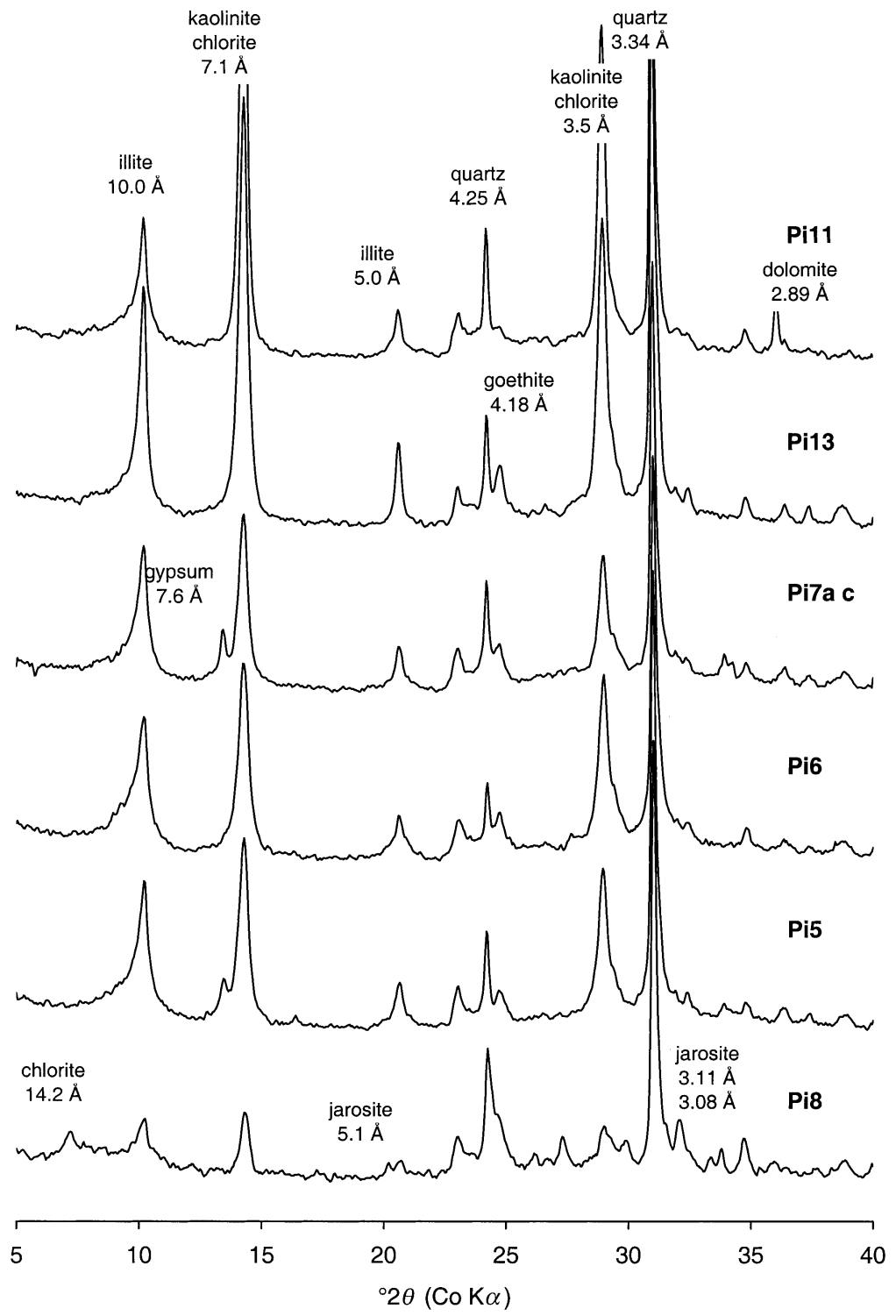

Fig. 5. X-ray diffraction curves of normal bedrock of the Gauja Formation (Pi11 - sandstone; Pi13 - clayey silt), matrix of fracture filling (Pi5 and Pi6), and clasts (Pi7a c). For comparison the curve of overlying Quaternary deposits is shown (Pi8).

\section{Mineralogical composition of clastic dikes}

The mineralogical composition of the $0.1-0.05 \mathrm{~mm}$ fraction of clastic dikes is rather close to that of the wall rock sandstones. Quartz is the dominating detrital mineral amounting almost always to $89-97 \%$ (Table 4). The quartz content 
is much lower $(16.8 \%)$ in the clayey siltstone from the Piusa quarry wall (sample Pi13). At the same time, in clayey silty clasts from fracture F1 with the same grain size distribution (Table 2, samples Pi4cc, Pi6cc, and Pi7a c) the quartz content is similar to the surrounding sandy deposits (Table 4). In the silty mixture of matrix and decomposed clasts from dike F4 of Piusa quarry (sample Pi12; Fig. 1; Table 4) the quartz content is between the two. In the overlying Quaternary sand above fracture F1, the amount of quartz is considerably lower (sample Pi8). In the Devonian, quartz grains are sub-angular to sub-rounded. Undulous extinction is observable in about $5-10 \%$ of grains. In the overlying Quaternary sandstone undulous grains make up more than $20 \%$ of the total. In wall rocks the quartz grains are mainly transparent. In fracture fillings 30-40\% and in sandstone clasts with goethite cement (samples Pi3csg and Pi6csg) up to $80 \%$ of grains are coated with goethitic film. The coatings have typically intense reddish-brown colour. In the Quaternary sandstone the amount of goethite-coated quartz grains is the same - about $70 \%$.

The content of orthoclase in all samples varies usually between 3 and $5 \%$. Small amounts of muscovite, biotite, plagioclase, and microcline are present. A higher content of micas is registered in silty samples. In Quaternary sandstone (sample Pi8) brown biotite occurs in large amounts. Findings of chalcedony and gypsum are occasional (Table 4).

In the heavy mineral spectrum ilmenite and transparent allothigenic minerals are prevailing in all studied rocks. Due to a higher content of goethite in the matrix of clastic dikes, the content of ilmenite and transparent allothigenic minerals is comparatively low (Table 5). Among heavy transparent minerals of the surrounding rocks and clastic dikes, zircon is dominating (40-60\%), accompanied by considerable amounts of tourmaline. The rest of the spectrum is composed mainly of the staurolite-rutile assemblage. Kyanite, garnet, monazite, and amphibole are common minerals, while apatite, anatase, titanite, corundum, pyroxene, and epidote are rare. Garnet occurs in large amounts in silty sediments and clasts. Clearly different is the mineralogical composition of the Quaternary deposits, where amphibole is the dominating heavy mineral (Pi8, Table 6).

The character of zircon and other heavy minerals in clastic dikes, including sandy and silty clasts, and reference rocks is similar. Zircon occurs as subhedral, short-prism, slightly rounded and mainly colourless grains. In the grain size class of $0.1-0.05 \mathrm{~mm}$ the proportion of coloured zircon is about $10 \%$. Brown, pink, and yellow varieties occur almost in equal amounts. Zoned grains account for 10-15\%. Permanently, but in minor amounts, multiedged grains are found. Tourmaline is predominantly green; the brown variety constitutes $5-15 \%$ of grains. In minor amounts, but permanently, blue tourmaline occurs. Rutile is represented mainly by short-prism slightly rounded brown to dark brown grains and a specific greenish-yellow variety with an amount of 25-30\%.

$\mathrm{X}$-ray diffraction analysis of the studied mineralogical composition of muddy particles showed besides general similarity to the normal composition of reference sandstones also some different features (Fig. 5). The muddy fraction of the sand- 
stones of the Gauja Formation is characterized by a considerably high content of kaolinite accompanied with illite (sample Pi11 in Fig. 5). In clayey-silty deposits the share of kaolinite is lower and the goethite supplement is characteristic (sample Pi13). The content of kaolinite is about two times smaller in sandy matrix of clastic dikes (samples Pi5 and Pi6) and clasts embedded in it (sample Pi7a c; Fig. 5), indicating that the fine-grained detrital material was partly derived from different sources. This is quite normal as migration abilities of fine material are greater. The occurrence of gypsum in many levels of fracture fillings (samples Pi5 and Pi7a c) is most likely connected with late or even present-day mineralizations. Quaternary sandstone has a clearly different (sample Pi8) composition, where this fraction is represented by a mixture of chlorite and illite and contains admixture of jarosite (Fig. 5).

For the geochemical comparison of clastic dikes and surrounding rocks, quantitative data of ten trace elements in muddy fraction were juxtaposed (Fig. 6). Geochemically matrix and clasts do not differ substantially from the surrounding bedrock. This is valid for two groups of elements: Rb, Y, and Th that are mainly related to feldspars and other clastic allothigenic minerals, and $\mathrm{Mn}$, $\mathrm{Ni}, \mathrm{Zn}, \mathrm{As}, \mathrm{Sr}, \mathrm{Pb}$, and $\mathrm{U}$, which could be carried also by clay minerals and most fine-grained, unspecified authigenic minerals. All Devonian samples, however,

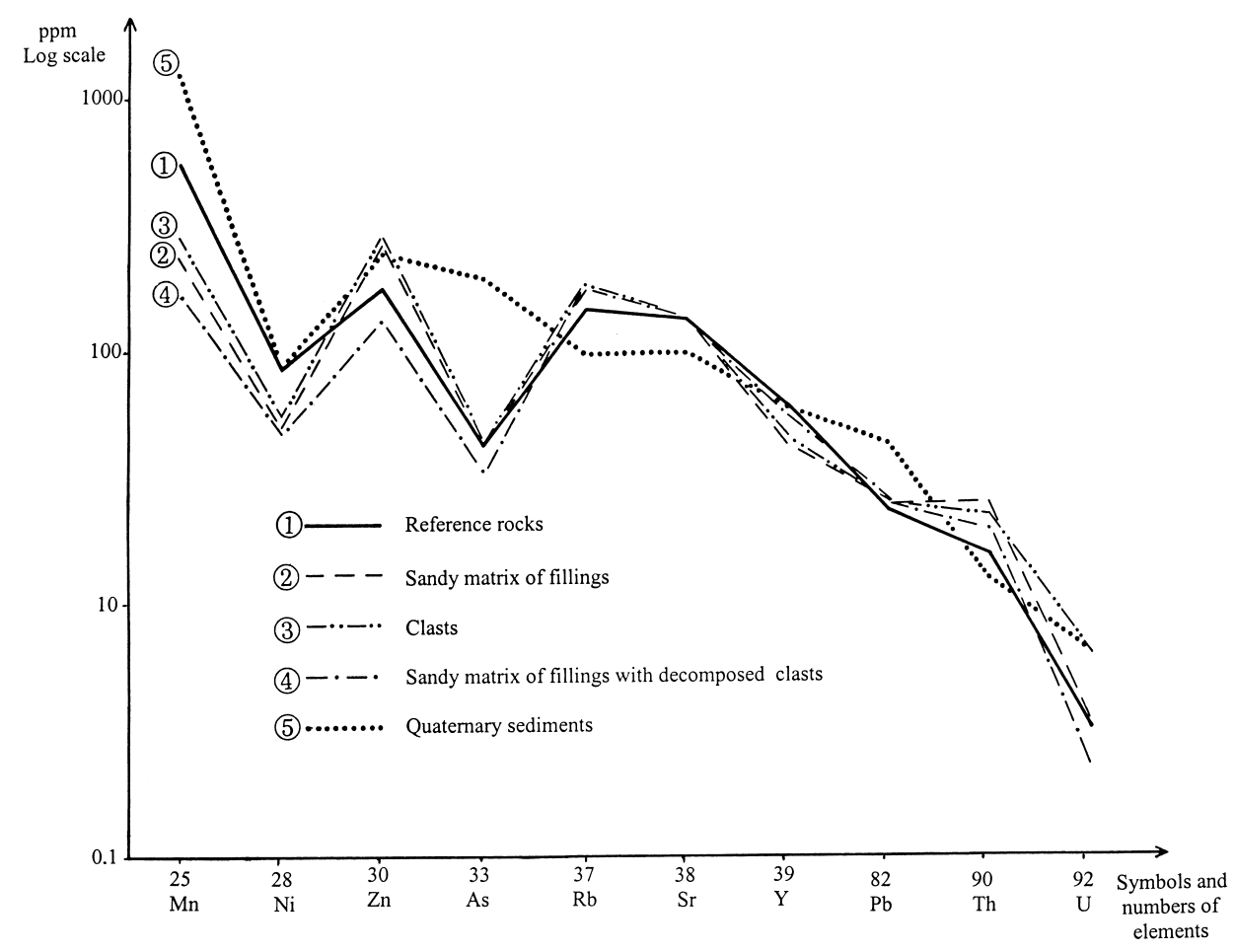

Fig. 6. Distribution of trace elements in wt $\%$ in mud fraction $(<0.01 \mathrm{~mm})$. 
differ significantly from a Quaternary sample which is enriched with Mn, As, and $\mathrm{Pb}$, and somewhat depleted in $\mathrm{Rb}$ and $\mathrm{Sr}$. The contents of $\mathrm{Rb}$ and Th within the dike are slightly higher, and $\mathrm{Mn}, \mathrm{Ni}$, and $\mathrm{Y}$ lower than in the surrounding rock.

\section{Diagenetic alterations}

As a whole, mineralogical and chemical data indicate that during the formation of the clastic dike and its subsequent history the authigenic mineralization process was negligible, except its enrichment with goethite. The data presented above reveal that clastic dikes are comparatively enriched with goethite component (Table 5; Fig. 5). Goethite has caused during the post-dike history stronger cementation of clastic dikes as compared to the surrounding rocks. As a result, the cementation rate is most increased in dikes F1 and F4 of Piusa quarry (Fig. 1B). The walls of fracture F1 are covered with a goethitic film (Fig. 7A). Along many bedding surfaces adjoining the fracture, goethite-rich interlayers and pockets were formed, which is illustrated by sample Pi10 (Fig. 7B). On detrital grains goethitic films are formed. The enrichment of sandstone clasts by goethite had a selective character; goethite concentrated mostly in the coarser varieties of sandstone (Tables 2 and 5; samples Pi3csg and Pi6csg). The portion of sandstone clasts in which kaolinitic cement is partially replaced by goethite is higher in the upper part of the fracture filling (Fig. 4A). Formation of goethite due to groundwater filtration is common in Devonian sandstones.
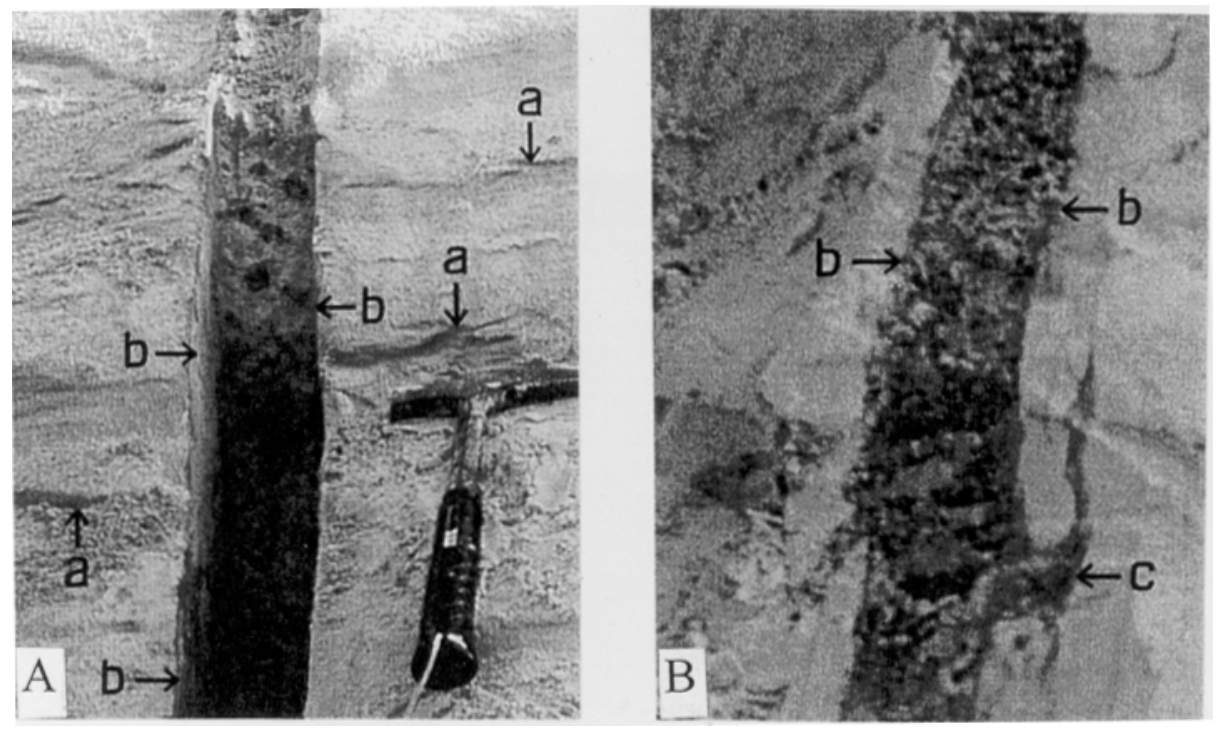

Fig. 7. Enrichment with goethite. (A) Concentration along bedding planes common in the surrounding rocks near fracture F1 (a) and on fracture surface (b). Photo by Ü. Sõstra. (B) Goethiterich pocket in wall rocks near fracture F1 (c). Photo by V. Puura. 
Fractures cutting the Devonian sandstone complex increase significantly the permeability of rocks and provide pathways for migration of fluids. Diagenetic changes in clastic dikes differ from those of the wall rock. In the fillings selective dissolution has taken place and the replacements of clay minerals can occur. In the clasts made up of clayey silt the micas were replaced by clay minerals. While in the reference rocks clayey silt consists mainly of mica minerals in the light fraction and green biotite among heavy minerals (sample Pi13), in clasts with the similar grain size (samples Pi4cc, Pi6cc, and Pi7a c) the content of micas is noticeably lower (Tables 4 and 5). These diagenetic changes have been continuing up to the present. Cementation by gypsum took place in the late phase of diagenesis and was possibly induced by replacement of authigenic pyrite or infiltration from the overlying Upper Devonian sulphate-bearing deposits.

\section{DISCUSSION AND CONCLUSIONS}

The exact stratigraphical extension of bedrock emplacing the clastic dikes of the Piusa-Tabina area is not firmly established. However, if the above hypothesis of the formation of the observed small synclinal folds is correct, the base of the fracturing should be deep below the Piusa quarry bottom level. On the other hand, the most probable source of clasts in the dikes was the flatland surface with specific arid-type eluvial sediments. It means that many tens of metres would be the minimum vertical extent of the once open fractures. Clastic dikes have been observed only in poorly cemented sandstone of the upper part of the Gauja Formation. Furthermore, they are always accompanying fold-like deformation structures in Devonian bedrock. The formation of fold-like structures and sporadically placed sections of open fractures are likely the results of the same compressional deformation phase, which could coincide with the aerial land uplift in the Haanja-Petseri branch of the regional Liepaja-Riga-Pskov dislocation zone (Puura \& Vaher 1997). An evidence of locally changing deformation rate is the WNW-SEE-trending clastic dike F3 in Piusa quarry, which within the $200 \mathrm{~m}$ stretch thins out to the closed fracture (Fig. 1B). In general, the strike of clastic dikes and synclines WNW $280-320^{\circ}$ coincides with the respective fracture system WNW $290-320^{\circ}$ in the Lode Member of the Gauja Formation.

The composition of clastic dikes is of special interest for estimating the provenance level in the geological section (Fig. 8). Clasts in dikes include rare complex, clast-in-clast varieties (Fig. 4D) and well-rounded strongly cemented sandstone pebbles, suggesting the existence of cemented and already once redeposited beds on the source surface. Such continental, eluvial, and temporary watering-evaporation-related sediments could form due to on-land processes in

arid Devonian climates. The conglomerate layer in the Gauja-Amata transition (Fig. 8) could be a representative of such sediments. 


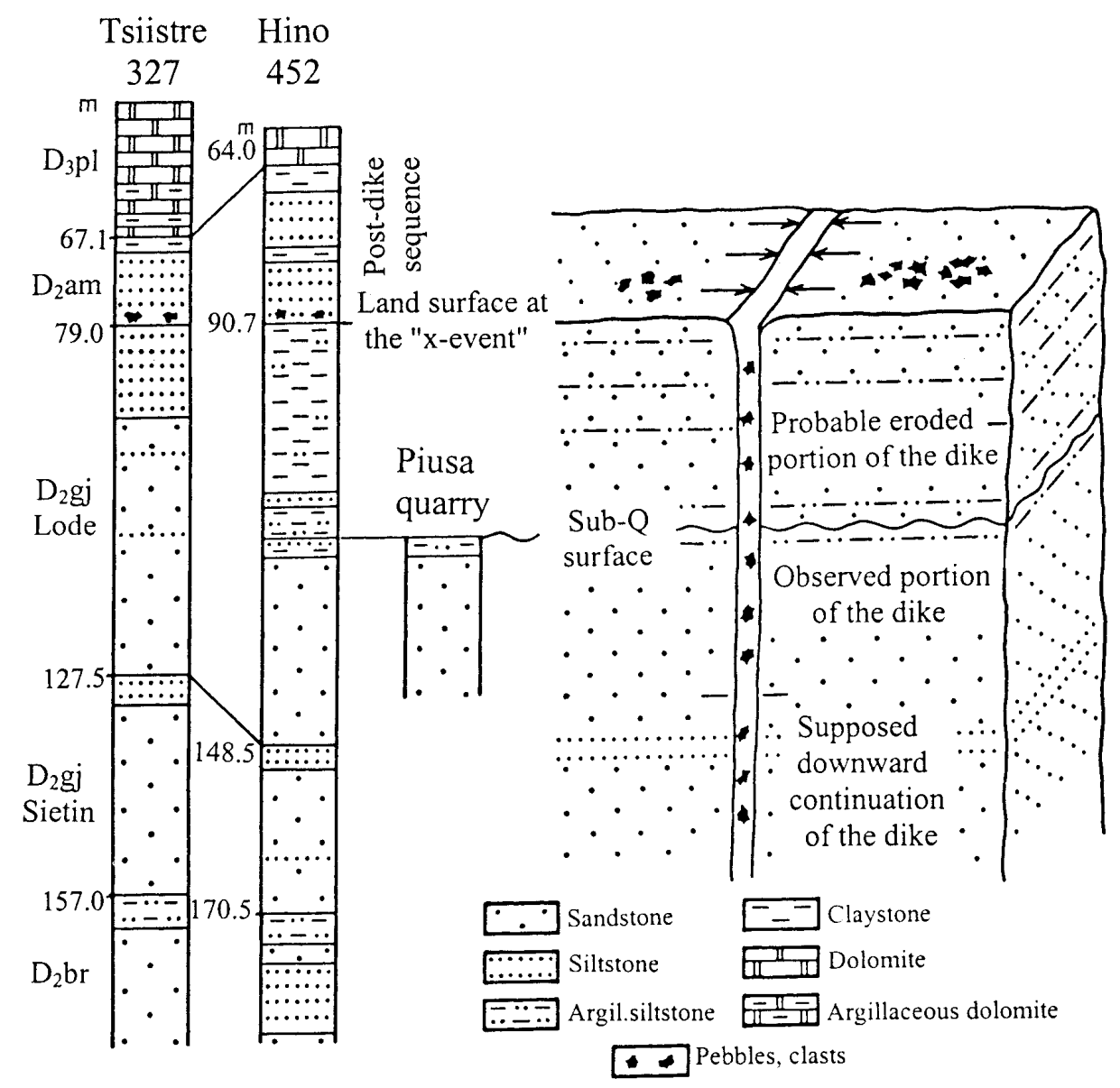

Fig. 8. Stratigraphical position of Piusa quarry in the sequence of the Gauja Formation and palaeogeological sketch of the "x-event" - supposed tectonic phase of the uplift of the territory when the formation and fracture filling took place. For abbreviations of Devonian stages see Fig. 1.

The high clast content, poor sorting, numerous angular clasts, and absence of bedding (Fig. 4B) suggest that the fracture fillings were deposited by rapid mass flows in subaerial conditions. Despite the little age difference between the sedimentation and fracturing, the walls of open fractures stayed stable. The sandstone beds had to be lithified enough to survive even surfaces of filled fractures. No indicative fossils are found in clastic dikes. Thus, the biostratigraphic age of the dikes remains unknown. Lithological and mineralogical data suggest that infilling immediately followed the formation of fractures. The lack of any material reminding of beds younger than the Gauja Formation suggests that the clastic dikes formed during Gauja time. Taking into consideration the total 
sequence of the Gauja Formation, and the position of Piusa quarry in it, the possible source level for the filling material, Gauja-Amata transition beds, was located some 20-30 m higher than the present-day bedrock surface (Fig. 8). The Gauja Formation is covered by the up to $20 \mathrm{~m}$ thick sandy Amata Formation, followed by carbonate deposits of the Plavinas Stage (Fig. 8). The lack of carbonate clasts indicates that no material has been derived from the Plavinas Stage.

Regarding the palaeohydrogeological conditions of dike formation and their development during the Late Palaeozoic to Cenozoic history, the above data allow some speculative conclusions. If our construction about the subaerial formation of fracture fillings at depths more than $20-30 \mathrm{~m}$ is correct, the sea-level drop had to be more than these figures. It suggests a considerably high stand of the land surface above sea level. A tectonic uplift event at the end-Gauja time could be an explanation. However, already in Amata time and the Late Devonian, the area with dikes was submerged under sea level. During the Late Palaeozoic to Cenozoic, the fluid-flow regime in the explored deposits was greatly affected by fractures, cross-cutting the poorly lithified sandstones of the Gauja Formation, which at least temporarily served as an aquifer. The fractures were highly permeable conduits for vertical flow of fluids. Watered and dry episodes of the rock massif alternated in the history, depending on the altitudes and relief of the territory. Iron-rich fluids precipitated goethite cement into the fracture fillings. The conditions during diagenesis differed in fracture fillings from the wall rock. In the fillings transformations of clay minerals and replacement of micas by clay minerals took place. During the late stage of diagenesis, in near-surface conditions certain new replacements and changes occurred. Due to alteration of authigenic pyrite, a minor content of gypsum cement formed.

The whole complex of geological and lithological observations and characteristics of grain-size, mineralogical, and trace element studies suggest that there is no relationship between clastic dikes and the overlying Quaternary deposits. The clastic dikes and also synclinal disturbances are of pre-Quaternary, most probably of late Middle Devonian age. The sources of the fracture fillings were soft disintegrated Devonian sandstone and clasts of Devonian, primarily lithified sandy and silty sediments of Gauja age.

\section{AKNOWLEDGEMENTS}

We acknowledge the constructive criticism and suggestions by I. Tuuling, Ü. Sõstra, E. Pirrus, and L. Ainsaar. We are also grateful to I. Puura for linguistic improvements, K. Ronk for drawings, and G. Baranov for taking photos. We thank E. Pirrus, Ü. Sõstra, T. Märss, and G. Baranov for permission to use their photos. The study was financed by the research projects Nos. $0332088 \mathrm{~s} 02$ and 0180551 s98 of the Ministry of Education of Estonia and grants Nos. 4417 (to V. Puura) and 4157 (to A. Shogenova) of the Estonian Science Foundation. 


\section{REFERENCES}

Bergman, L. 1982. Clastic dikes in the Aland Islands, SW Finland, and their origin. Geol. Surv. Finland Bull., 317, 8-33.

Heinsalu, Ü. \& Andra, H. 1975. Jointing in Oil-Shale Basin and Geophysical Research Methods for Its Study. Valgus, Tallinn (in Russian).

Indans, A. P. 1962. Tektonicheskaya struktura Latvii. Izd. Akademii nauk Latv. SSR, Riga (in Russian).

Kajak, K. 1997. Upper Devonian. In Geology and Mineral Resources of Estonia (Raukas, A. \& Teedumäe, A., eds.), pp. 121-123. Estonian Academy Publishers, Tallinn.

Kaplan, A. \& Hasanovitch, K. 1969. On the question of tectonic development of the Lokno High. In Voprosy regional'noj geologii Pribaltiki i Belorussii (Volkolakov, F. G., ed.), pp. 101-113. Riga (in Russian).

Kleesment, A. 1995. Lithological characteristics of the uppermost terrigenous Devonian complex in Estonia. Proc. Estonian Acad. Sci. Geol., 44, 221-233.

Kleesment, A. 1997. Devonian sedimentation basin. In Geology and Mineral Resources of Estonia (Raukas, A. \& Teedumäe, A., eds.), pp. 205-208. Estonian Academy Publishers, Tallinn.

Kleesment, A. \& Mark-Kurik, E. 1997. Middle Devonian. In Geology and Mineral Resources of Estonia (Raukas, A. \& Teedumäe, A., eds.), pp. 112-121. Estonian Academy Publishers, Tallinn.

Kleesment, A. \& Pirrus, E. 2000. Fracture systems in Devonian sandstones, South Estonia. Proc. Estonian Acad. Sci. Geol., 49, 284-293.

Kuršs, V. M. 1992. Devonskoe terrigennoe osadkonakoplenie na Glavnom devonskom pole. Zinatne, Riga (in Russian).

Miidel, A. 1982. On the interdependence between the fracturing of the Devonian rocks and the direction of the valley of the Võhandu River at its middle course (South Estonia). ENSV TA Toim. Geol., 31, 80 (in Russian).

Orviku, K. K. 1960. On the lithostratigraphy of the Volkhov and Kunda stages of Estonia. ENSV TA Geol. Inst. Uurimused, V, 45-88 (in Russian).

Pani, T. \& Mark-Kurik, E. 1995. Piusa klaasiliivakaevandus. In Liivimaa geoloogia. Ekskursioonijuht (Ainsaar, L. \& Kirsimäe, K., eds.), pp. 14-15. Tartu, TÜ, EGS.

Pirrus, E., Kleesment, A. \& Sööt, M. 2002. Joint systems in Devonian sandstones in the KiidjärveTaevaskoda research area, Southeast Estonia. Proc. Estonian Acad. Sci. Geol., 51, 121-132.

Plink-Björklund, P. \& Björklund, L. 1999. Sedimentary response in the Baltic Devonian Basin to postcollisional events in the Scandinavian Caledonides. GFF, 121, 79-80.

Puura, V. \& Vaher, R. 1997. Cover structure. In Geology and Mineral Resources of Estonia (Raukas, A. \& Teedumäe, A., eds.), pp. 167-177, Estonian Academy Publishers, Tallinn.

Sinisalu, R. 1997. Imara-Tabina liivaleiukoha geoloogilisest uurimisest. EGK Aastaraamat 1996. Tallinn, 85-86.

Suveizdis, P. I. (ed.). 1979. Baltic Tectonics. Mokslas, Vilnius (in Russian).

Sõstra, Ü. 1997. Tektoonilised maakoorerikked Piusa karjääris. Eesti Loodus, 6, 268-269.

Tynni, R. 1982. On Paleozoic microfossils in clastic dikes on the Aland Islands. Geol. Surv. Finland Bull., 317, 36-115.

Vaher, R. M., Raukas, A. V. \& Tavast, E. H. 1980. The influence of tectonics and bedrock topography on the formation on insular heights at Estonia. Geomorphologiya, 3, 55-65 (in Russian). 


\title{
Settesooned Kesk-Devoni Gauja kihistu liivakivides Kagu-Eestis
}

\begin{abstract}
Anne Kleesment, Väino Puura ja Toivo Kallaste
Settesooned on Baltoskandia alampaleosoilistes kihtides harva esinevad, kuid tähelepanuväärsed objektid, mis annavad olulist informatsiooni geoloogilise mineviku sündmuste taastamisel. Eesti Devoni läbilõikest leiti esimesed kuni $10 \mathrm{~cm}$ paksused settesooned Gauja lademe kivimites Piusa ja Tabina klaasiliivakarjääris. Välivaatluste, litoloogilis-mineraloogiliste ja geokeemiliste uuringute tulemusel selgitati, et nende formeerumine toimus lühiajalise settekatkestuse ajal Kesk-Devoni lõpul. Vaadeldavate soonte täitematerjaliks olid tõenäoliselt Gauja ea eluviaalsed setted, mis eelnevalt olid kuivas troopilises keskkonnas osaliselt jõudnud tsementeeruda. Lõhesid täitev liivakas põhimass, milles on rohkesti aleuriitseid ja liivakaid veeriseid, kanti avalõhedesse varingu ja ajutiste veevoolude toimel subaeraalsetes oludes. Veega transpordi tagasihoidlikku osa näitab kihilisuse puudumine soont täitvas purdmaterjalis.

Avatud lõhede teke oli arvatavasti seotud tektoonilise aktiivsuse tõusuga hiliskaledoonilisel etapil tekkinud Liepaja-Riia-Pihkva dislokatsioonivöös ja see põhjustas vaadeldava ala kerke. Lõhed täitusid vahetult pärast nende avanemist. Sellel ajal pidi tänapäeva liivakarjääre hõlmav ala olema kerkinud 20-30 m üle põhjavee taseme. Järgnenud vajumise tõttu sattusid formeerunud settesooned aktiivsete vete tsirkulatsioonivööndisse, mille tagajärjel toimusid neis götiitne tsementatsioon ja mõningad teised diageneetilised protsessid.
\end{abstract}

